Jurnal Ilmu Ilmu Agribisnis: Journal of Agribusiness Science, 9(3), Agustus 2021

\title{
ANALISIS PENDAPATAN USAHATANI LADA HITAM DAN TINGKAT KESEJAHTERAAN RUMAH TANGGA DI KECAMATAN MELINTING KABUPATEN LAMPUNG TIMUR
}

\author{
(Analysis of Pepper Farming Income and Household Welfare Levels in Kecamatan Melinting \\ East Lampung District)
}

\author{
Bella Apriliana, Teguh Endaryanto, Lina Marlina
}

Jurusan Agribisnis, Fakultas Pertanian, Universitas Lampung, J1. Prof. Dr. Soemantri Brojonegoro No. 1
Bandar Lampung 35145, e-mail: teguh.endaryanto@ @fp.unila.ac.id

\begin{abstract}
This research aims to analyze the income and welfare levels of of pepper farmers in Melinting Sub-District, East Lampung Regency. The location of the research is chosen purposively. The number of respondents in this reasearch is 43 farmers who are selected using simple random sampling. The methods of analysis used in this research are quantitative method to calculate household income and descriptive qualitative method to determine welfare levels. The results of this research showed that the total income of pepper farming is included in the low category which is IDR1691,026.16 per month with the contribution of 25.63 percent towards household income. Based on the criteria of Badan Pusat Statistik in 2014, 100 percent of pepper farmer households are in the prosperous category, while 20.93 percent included in the high welfare category based on the subjective welfare indicators.
\end{abstract}

Key words: household, income, pepper, welfare.

\section{PENDAHULUAN}

Indonesia merupakan salah satu negara penghasil dan penyumbang ekspor lada terbesar di dunia. Perkembangan komoditas lada dalam negeri dihadapkan pada permasalahan baik dari eksternal maupun internal petani. Jumlah produksi yang berfluktuasi akan berdampak pada jumlah dan nilai ekspor lada Indonesia. Jumlah ekspor lada Indonesia terus mengalami penurunan dari tahun 2015-2018. Penurunan jumlah ekspor tersebut juga diimbangi dengan penurunan harga lada, baik harga lada Indonesia maupun harga lada dunia (BPS 2019).

Menurut Kementerian Pertanian Republik Indonesia (2018), Provinsi Lampung masih menduduki urutan terbesar pertama sebagai penghasil lada hitam di Indonesia. Jumlah produksi lada tertinggi terjadi pada tahun 2013 sebesar 2.6654 ton. Sejak tahun 2010-2017 terjadi pertumbuhan rata-rata sebesar $(-5,42 \%)$ per tahun. Hal tersebut menunjukkan bahwa setiap tahunnya terjadi penurunan jumlah produksi lada.

Dinas Perkebunan Provinsi Lampung (2017) menyatakan bahwa Kabupaten Lampung Timur merupakan salah satu daerah yang memiliki potensi besar dalam perkembangan komoditas lada. Kabupaten Lampung Timur termasuk ke dalam 5 daerah sentra penghasil lada terbesar di Provinsi Lampung. Berdasarkan data Dinas
Perkebunan Provinsi Lampung (2017), produksi lada di Kabupaten Lampung Timur juga ikut mengalami penurunan yang sangat signifikan dari tahun sebelumya. Pada tahun 2016, produksi lada menunjukkan angka 1.634 ton. Hal tersebut menunjukkan bahwa terjadi penurunan produksi sebesar 324 ton dari tahun 2015 dengan jumlah 1.958 ton, namun penurunan jumlah produksi yang terjadi tidak seiring dengan luas areal tanam yang cenderung konstan dari tahun 2015-2016 yaitu seluas 3.031 ha.

Menurut Kementerian Pertanian Republik Indonesia (2017) terjadi perbedaan yang sangat signifikan, dimana harga lada hitam di Provinsi Lampung pada tahun 2015 sebesar Rp103.500,00 per $\mathrm{kg}$, sedangkan harga yang diterima petani di Kabupaten Lampung Timur hanya menyentuh angka maksimal sebesar Rp78.588,00 per kg. Harga tersebut terus menerus menurun hingga tahun 2017. Hal tersebut tentunya akan sangat berpengaruh terhadap penerimaan dan pendapatan yang diterima petani dari usahatani lada yang dilakukannya.

Meliyana, Zakaria dan Nurmayasari (2013) menyatakan bahwa tingginya tingkat persaingan antarnegara akan produktivitas tanaman lada tidak hanya berdampak pada perekonomian Indonesia secara keseluruhan, tetapi juga akan berdampak langsung pada perekonomian daerah. Penerimaan usahatani yang menurun tanpa diikuti oleh 
penurunan biaya produksi akan menyebabkan pendapatan dari usahatani tersebut akan terus menurun, sehingga menimbulkan kesulitan dalam pengalokasiannya. Apabila pendapatan yang diterima tidak dapat mencukupi kebutuhan rumah tangga, maka hal tersebut akan berdampak negatif terhadap tingkat kesejahteraan petani. Semakin banyak petani yang tidak sejahtera, maka akan semakin meningkatkan jumlah penduduk miskin di suatu wilayah. Selain berpengaruh terhadap tingkat kesejahteraan secara objektif, pendapatan yang semakin menurun akan mendorong petani untuk mencari pendapatan tambahan dengan melakukan berbagai usaha baik dari on farm, non lada, off farm, ataupun non farm. Tujuan dari penelitian ini adalah menganalisis besarnya pendapatan usahatani lada, besarnya pendapatan rumah tangga petani lada, dan menganalisis tingkat kesejahteraan rumah tangga petani lada di Kecamatan Melinting.

\section{METODE PENELITIAN}

Metode penelitian yang digunakan adalah metode survei. Pemilihan lokasi penelitian dilakukan sengaja (purposive) di Kecamatan Melinting, Kabupaten Lampung Timur dengan pertimbangan Kecamatan Melinting merupakan daerah dengan luas tanaman perkebunan lada terbesar pertama di Kabupaten lampung Timur.

Responden penelitian adalah petani yang membudidayakan tanaman lada yang berada pada Desa Sumberhadi. Pemilihan desa tersebut dilakukan secara sengaja (purposive) dengan pertimbangan bahwa Desa Sumberhadi merupakan satu-satunya desa dengan petani lada yang memiliki tanaman lada yang berada pada usia produktif. Metode pengambilan sampel menggunakan metode simple random sampling yang mengacu pada teori Isaac dan Michael (1981) dalam Sugiarto (2003) dengan pertimbangan bahwa responden di daerah penelitian cenderung homogen dalam penguasaan lahan dan penggunaan input. Hasil perhitungan didapatkan bahwa sampel yang digunakan sebanyak 43 petani yang berada di Desa Sumberhadi.

Pengambilan data dilakukan pada Februari 2020. Jenis data yang digunakan yaitu data primer dan data sekunder. Data primer diambil langsung dari petani lada melalui teknik wawancara dengan metode survei terhadap sampel dari populasi dengan menggunakan sejumlah pertanyaan (kuesioner) sebagai alat untuk memperoleh data pokok. Data sekunder diperoleh dari sumber- sumber berupa literatur yang berkaitan dengan topik penelitian. Metode analisis data yang digunakan adalah analisis kuantitatif dan kualitatif.

Pendapatan rumah tangga merupakan hasil pengakumulasian seluruh pendapatan petani baik dari sumber on farm, off farm, dan non farm (Prasetio, Widjaya, dan Murniati, 2020). Pada penelitian ini pendapatan on farm diperoleh dari pendapatan on farm lada dan pendapatan on farm non lada. Rumus yang digunakan:

$\mathrm{P}_{\mathrm{rt}}=\mathrm{P}_{\text {on farm lada }}+\mathrm{P}_{\text {on farm non lada }}+\mathrm{P}_{\text {off farm }}+\mathrm{P}_{\text {non farm }}$.... (1)

Keterangan:

$\mathrm{P}_{\mathrm{rt}} \quad=$ Pendapatan rumah tangga lada per.tahun......

$\mathrm{P}_{\text {on farm lada }}=$ Pendapatan dari usahatani lada

$\mathrm{P}_{\text {on farm non lada }}=$ Pendapatan dari usahatani selain lada

$\mathrm{P}_{\text {off farm }} \quad=$ Pendapatan di bidang pertanian di luar usahatani

$\mathrm{P}_{\text {non farm }} \quad=$ Pendapatan non pertanian

Menurut Patra, Ismono, dan Nugraha (2019), pendapatan usahatani adalah selisih antara seluruh penerimaan yang didapatkan dan biaya yang dikeluarkan dalam kegiatan usahatani. Perhitungan pendapatan usahatani lada mengunakan rumus sebagai berikut (Soekartawi 2002):

$\pi=\mathrm{Y} . \mathrm{Py}-\sum \mathrm{Xi} \cdot \mathrm{Pxi}$

$$
\begin{array}{ll}
\text { Keterangan: } & \\
\pi & =\text { Pendapatan }(\mathrm{Rp}) \\
\mathrm{Y} & =\text { Produksi }(\mathrm{Kg}) \\
\mathrm{Py} & =\text { Harga produksi }(\mathrm{Rp}) \\
\mathrm{X} & =\text { Faktor produksi }(\mathrm{i}=1,2,3, . ., \mathrm{n}) \\
\mathrm{Px} & =\text { Harga faktor produksi }(\mathrm{Rp})
\end{array}
$$

BPS (2016) membagi pendapatan rumah tangga menjadi empat golongan yaitu:

1. Jika pendapatan rata-rata lebih besar dari Rp6.000.000,00 per bulan, maka termasuk dalam golongan pendapatan sangat tinggi.

2. Jika pendapatan rata-rata antara Rp4.000.000,00 - Rp6.000.000,00 per bulan, maka termasuk golongan pendapatan tinggi.

3. Jika pendapatan rata-rata antara Rp2.000.000,00 - Rp4.000.000,00 per bulan, maka termasuk dalam golongan pendapatan sedang.

4. Jika pendapatan rata-rata $\mathrm{Rp} 2.000 .000,00$ per bulan, maka termasuk dalam golongan pendapatan rendah. 
Kontribusi pendapatan adalah ukuran penyebaran pembagian pendapatan dari tiap sumber pendapatan terhadap total keseluruhan pendapatan rumah tangga petani (Canita, Haryono, dan Kasmir, 2017). Kontribusi usahatani lada terhadap pendapatan rumah tangga petani dapat dihitung dengan menggunakan rumus :

Kontribusi $=\frac{\text { Pendapatan usahatani lads }}{\text { Pendapatan rumah tangga }} \times 100 \%$

Keterangan:

Pendapatan usahatani $\quad=$ Pendapatan usahatani lada

Pendapatan rumah tangga $=$ Pendapatan keseluruhan dari rumah tangga petani

Menurut Simamora, Zakaria dan Kasymir (2020), kemiskinan dan kesejahteraan merupakan keadaan yang berkaitan karena penurunan tingkat kemiskinan, maka akan berpengaruh terhadap tingkat kesejahteraan. Tingkat kesejahteraan rumah tangga petani lada di Kecamatan Melinting dianalisis dengan menggunakan dua kriteria. Analisis tingkat kesejahteraan petani menurut kriteria BPS (2014) yang diukur melalui pendekatan tujuh indikator yang terdiri dari kependudukan, kesehatan dan gizi, pendidikan, ketenagakerjaan, taraf dan pola konsumsi, perumahan dan lingkungan, sosial dan lain-lain dengan klasifikasi yang digunakan yaitu sejahtera dan belum sejahtera. Variabel pengamatan disertai dengan klasifikasi dan skor yang dapat mewakili besaran klasifikasi indikator tersebut. Skor tingkat klasifikasi pada tujuh indikator kesejahteraan dihitung berdasarkan pedoman penentuan Range Score. Rumus penentuan range score adalah:

$$
\mathrm{RS}=\frac{\text { SKT-SKR }}{\text { KKL }} \text {. }
$$

Keterangan:

$$
\begin{array}{ll}
\text { RS } & =\text { Range score } \\
\text { SKT } & =\text { Skor tertinggi }(7 \times 3=21) \\
\text { SKR } & =\text { Skor terendah }(7 \times 1=7) \\
\text { JKL } & =\text { Jumlah klasifikasi }
\end{array}
$$

Hasil perhitungan berdasarkan rumus tersebut diperoleh Range Score (RS) sama dengan tujuh, sehingga dapat dilihat interval skor yang akan menggambarkan tingkat kesejahteraan rumah tangga petani lada. Hubungan antara interval skor dan tingkat kesejahteraan adalah:

1. Jika skor antara 7-14 berarti rumah tangga petani belum sejahtera.

2. Jika skor antara 15-21 berarti rumah tangga petani sejahtera.

Analisis kesejahteraan rumah tangga petani lada subjektif diukur dengan menggunakan indikator empat dimensi yang dimodifikasi dari penelitian Muhsin (2014). Dimensi yang digunakan yaitu dimensi fisik, ekonomi, sosial dan psikologi yang terbagi ke dalam 27 pertanyaan dengan jawaban berupa skala likert (1-3) dan menghasilkan tiga klasifikasi yaitu sejahtera rendah, sedang dan tinggi. Hasil uji validitas dan realibilitas komponen-komponen pertanyaan kesejahteraan subjektif menunjukkan rata-rata sebesar 0,513 dan 0,882 yang berarti bahwa kuisioner valid dan dapat dipercaya untuk mendapatkan informasi mengenai kesejahteraan subjektif petani lada.

\section{HASIL DAN PEMBAHASAN}

\section{Keragaan Usahatani Lada}

Usia responden petani lada di Kecamatan Melinting berkisar antara 30-68 tahun dengan tingkat pendidikan SMP dan pengalaman berusahatani >10 tahun. Rata-rata luas lahan yang dikuasai oleh petani lada di Kecamatan Melinting yaitu 0,94 ha yang berstatus milik pribadi. Varietas lada yang dibudidayakan Natar 1 dengan perawatan berupa pemupukan NPK, KCl, TSP36, Urea, Phonska, serta pupuk kandang sebanyak satu kali dalam setahun dan penyemprotan HPT dengan pestisida sidametrin dan regent. Rata-rata tanaman lada di Kecamatan Melinting berusia lebih dari 10 tahun dengan nilai produktivitas $431,17 \mathrm{~kg} / \mathrm{ha} /$ tahun. Tanaman lada di Kecamatan Melinting mulai berproduksi pada tahun ke empat dan dapat berproduksi besar atau panen raya setiap 3 kali masa panen. Kegiatan panen lada dilakukan antara Bulan Agustus - Oktober. Pada umumnya, petani lada di Kecamatan Melinting menggunakan tenaga kerja dari luar keluarga dengan upah sebesar Rp70.000,00 per orang/hari. Hasil panen akan langsung didistribusikan ke tengkulak atau pasar terdekat.

\section{Analisis Biaya dan Pendapatan Usahatani Lada}

Tabel 1 menunjukkan bahwa rata-rata penggunaan lahan di Kecamatan Melinting adalah 0,94 ha dengan produktivitas $405,81 \mathrm{~kg} / \mathrm{ha} /$ tahun. Harga jual lada yang diterima petani pada musim panen 
Tabel 1. Rata-rata penerimaan, biaya, dan pendapatan usahatani lada hitam di Kecamatan Melinting.

\begin{tabular}{|c|c|c|c|c|c|c|c|}
\hline \multirow{2}{*}{ No } & \multirow{2}{*}{ Uraian } & \multicolumn{3}{|c|}{ Per $0,94 \mathrm{Ha}$} & \multicolumn{3}{|c|}{ Per $1 \mathrm{Ha}$} \\
\hline & & Satuan & Jumlah & Harga & Nilai & Jumlah & Nilai \\
\hline \multirow[t]{2}{*}{1} & Penerimaan & & & & & & \\
\hline & Produksi & $\mathrm{Kg}$ & 405,81 & $20.000,00$ & $8.116 .200,00$ & 431,71 & $8.634 .255,32$ \\
\hline \multirow[t]{25}{*}{2} & Biaya Produksi & & & & & & \\
\hline & I. Biaya Tunai & & & & & & \\
\hline & Pupuk Kandang & $\mathrm{Kg}$ & 56,98 & $2.550,00$ & $145.290,70$ & 60,61 & $154.564,57$ \\
\hline & Pupuk KCL & $\mathrm{Kg}$ & 20,23 & $2.200,00$ & $44.511,63$ & 21,52 & $47.352,80$ \\
\hline & Pupuk TSP36 & $\mathrm{Kg}$ & 3,49 & $2.600,00$ & $9.069,77$ & 3,71 & $9.648,69$ \\
\hline & Pupuk Urea & $\mathrm{Kg}$ & 9,88 & $2.000,00$ & $19.767,44$ & 10,51 & $21.029,19$ \\
\hline & Pupuk Phonska & $\mathrm{Kg}$ & 16,63 & $3.000,00$ & $49.883,72$ & 17,69 & $53.067,79$ \\
\hline & Pupuk NPK & $\mathrm{Kg}$ & 2,33 & $2.300,00$ & $5.348,84$ & 2,47 & $5.690,25$ \\
\hline & Pest. Sidametrin & $\mathrm{Lt}$ & 0,20 & $85.000,00$ & $17.274,19$ & 0,22 & $18.376,80$ \\
\hline & Pest. Regent & $\mathrm{Lt}$ & 0,16 & $73.333,33$ & $11.511,63$ & 0,17 & $12.246,41$ \\
\hline & TKLK & HOK & 21,94 & $70.000,00$ & $2.530 .930,23$ & 23,34 & $2.692 .478,97$ \\
\hline & Pajak & $\mathrm{Rp}$ & & & $51.860,47$ & & $55.170,71$ \\
\hline & Biaya Transportasi & $\mathrm{Rp}$ & & & $24.465,12$ & & $26.026,72$ \\
\hline & Total B. Tunai & & & & $2.915 .872,09$ & & $3.101 .991,59$ \\
\hline & II. Biaya Diperhitungkan & & & & - & - & - \\
\hline & Penyusutan Alat & $\mathrm{Rp}$ & & & $370.092,24$ & & $393.715,15$ \\
\hline & TKDK & HOK & 63,29 & $70.000,00$ & $5.902 .558,14$ & 67,33 & $6.279 .317,17$ \\
\hline & Total B. Diperhitungkan & $\mathrm{Rp}$ & & & $6.272 .650,38$ & & $6.673 .032,32$ \\
\hline & III. Biaya Total & & & & $9.188 .522,47$ & & $9.775 .023,91$ \\
\hline & IV. Pendapatan & & & & - & & . \\
\hline & Pend. Atas B. Tunai & $\mathrm{Rp}$ & & & $5.200 .406,98$ & & $5.532 .347,85$ \\
\hline & Pend. Atas B. Total & $\mathrm{Rp}$ & & & $(1.072 .322,47)$ & & $(1.140 .768,59)$ \\
\hline & V. R/C & & & & - & & - \\
\hline & R/C Biaya Tunai & & & & 2,78 & & 2,78 \\
\hline & R/C Biaya Total & & & & 0,88 & & 0,88 \\
\hline
\end{tabular}

tahun 2019 yaitu Rp20.000,00/kg. Pendapatan petani atas biaya tunai sebesar Rp5.532.347,85/ha, dan pendapatan atas biaya total sebesar $\mathrm{Rp}(-$ 1.140.768,59). Hasil perhitungan rasio antara penerimaan dan biaya tunai yang harus dikeluarkan menunjukkan angka 2,78. Nilai tersebut menunjukkan bahwa usahatani lada di Kecamatan Melinting tergolong menguntungkan, karena nilai $\mathrm{R} / \mathrm{C}>1$. Hasil tersebut sejalan dengan penelitian Handini, Abidin, dan Hassanudin (2019).

Walaupun secara tunai termasuk menguntungkan, namun jika dilihat dari rasio antara penerimaan dan biaya total dengan nilai sebesar 0,88 maka dapat diartikan bahwa setiap biaya yang dikeluarkan sebesar Rp1,00 maka akan menghasilkan penerimaan total sebesar $\mathrm{Rp} 0,88$. Hal tersebut dapat diartikan bahwa secara total usaha tani lada di Kecamatan Melinting belum menguntungkan. Hasil R/C atas biaya total yang menunjukkan kerugian tersebut disebabkan karena harga lada yang diterima petani sangat rendah dibandingkan harga jual lada hitam pada tahun-tahun sebelumnya.

Pensimulasian dilakukan dengan menguji pada tingkat harga berapakah $\mathrm{R} / \mathrm{C}$ atas biaya total dapat menunjukkan keuntungan minimum atau nilai impas. Hasil percobaan menunjukkan bahwa pada

harga $\mathrm{Rp} 22.630,00 / \mathrm{kg}$ petani baru mecapai titik impas dengan $\mathrm{R} / \mathrm{C}$ atas biaya total pada luas lahan 0,94 sebesar 1,00. Rata-rata penerimaan, biaya,dan pendapatan usahatani lada di Kecamatan Melinting dapat dilihat pada Tabel 1.

\section{Pendapatan Rumah Tangga Petani Lada}

Hasil penelitian menunjukkan sumber pendapatan rumah tangga petani lada di Kecamatan Melinting berasal dari sumber kegiatan on farm lada, on farm non lada, off farm, dan non farm dengan jumlah sebesar Rp20.292.313,96. Jika dikonversikan dalam satu bulan maka pendapatan yang diperoleh sebesar Rp1.691.026,16 per bulan.

Pada Tabel 2 dapat dilihat kontribusi pendapatan usahatani lada terhadap pendapatan rumah tangga hanya mencapai 25,63 persen. Petani beranggapan bahwa, pada tahun-tahun sebelumnya ketika harga jual lada masih berada pada rentang harga Rp60.000- Rp100.000, pendapatan dari sektor on farm lada merupakan pendapatan utama dan memiliki kontribusi yang besar dibanding sektor usaha lain. 
Tabel 2. Sebaran komponen pendapatan petani lada di Kecamatan Melinting.

\begin{tabular}{llrc}
\hline No & \multicolumn{1}{c}{ Komponen } & \multicolumn{1}{c}{$\begin{array}{c}\text { Nilai } \\
(\mathrm{Rp})\end{array}$} & $\begin{array}{c}\text { Kontribusi } \\
(\%)\end{array}$ \\
\hline 1 & On farm lada & $5.200 .406,98$ & 25,63 \\
2 & On farm non lada & $2.047 .720,93$ & \\
& Kelapa & $862.790,70$ & \\
& Duku & $151.162,79$ & 10,09 \\
& Pisang & $182.604,65$ & \\
& Tanaman lainnya & $906.976,74$ & \\
3 & Off farm & $3.727 .906,98$ & \\
& Buruh tani & $1.355 .813,96$ & 18,37 \\
Jual-beli hasil pertanian & $2.372 .093,02$ & \\
4 & Non farm & $9.316 .279,07$ & \\
& Berdagang & $1.186 .046,51$ & 45,91 \\
& Kuli/Buruh bangunan & $8.013 .953,49$ & \\
& Usaha lainnya & $116.279,07$ & \\
\hline & Jumlah & $20.292 .313,96$ & 100,00 \\
\hline
\end{tabular}

Jika disimulasikan pada harga lada pada tahun sebelumya yaitu tahun 2018 dengan tingkat harga Rp80.000,00/ kg, maka angka kontribusi dari komponen pendapatan on farm lada terhadap pendapatan rumahtangga yaitu sebesar 65,23 persen atau sebesar Rp29.179.151,95/ tahun. Harga yang rendah akan memperkecil kontribusi komponen on farm lada terhadap pendapatan rumah tangga begitu juga sebaliknya. Sebaran komponen pendapatan rumah tangga petani lada di Kecamatan Melinting dapat dilihat pada Tabel 2.

Selain harga, kuantitas panen lada juga berpengaruh terhadap kontribusi pendapatan on farm terhadap pendapatan rumah tangga. Hal tersebut sejalan dengan penelitian Togatorop, Haryono, dan Rosanti (2014). Semakin menurun jumlah produksi lada, maka jumlah penerimaan yang didapatkan petani juga semakin menurun. Menurut hasil wawancara dengan petani lada di Kecamatan Melinting, produksi lada mengalami penurunan dalam 5 tahun terakhir. Penyebab utama dari penurunan hasil panen tersebut adalah semakin banyaknya hama yang menyerang

terutama hama ulat nyess dan tidak sesuainya pemberian dosis pupuk, pestisida, serta perawatan yang dilakukan oleh petani dengan anjuran yang telah ada. Dampak negatif juga akan terjadi apabila trend penurunan harga jual lada di tingkat petani terjadi dalam rentang waktu yang lebih lama, dikhawatirkan hal tersebut akan mempengaruhi keenganan petani untuk terus membudidayakan tanaman lada.

\section{Kesejahteraan Rumah Tangga Petani Lada Berdasarkan Indikator BPS (2014)}

Pada Tabel 3, hasil penelitian menunjukkan bahwa indikator dengan kategori mayoritas baik meliputi kesehatan dan gizi, ketenagakerjaan, serta perumahan dan lingkungan, sedangkan indikator dengan kategori cukup meliputi kependudukan, pendidikan, taraf dan pola konsumsi dan sosial serta lain-lain. Hal tersebut menunjukan bahwa rumah tangga petani lada di Kecamatan Melinting secara garis besar berada pada kondisi cukup dan baik. Perbedaan pencapaian dari setiap indikator disebabkan karena perbedaan keputusan petani dalam mengutamakan pengalokasian dari pendapatan yang diterima. Rata-rata perolehan kelas dari setiap indikator kesejahteraan menurut indikator BPS (2014) di Kecamatan Melinting dapat dilihat pada Tabel 3. Hasil penelitian menunjukkan bahwa secara keseluruhan responden petani lada di Kecamatan Melinting merupakan rumah tangga dengan kategori sejahtera. Hal ini disebabkan penurunan harga jual lada yang secara drastis pada kurun waktu satu tahun terakhir belum berdampak secara fisik terhadap tingkat kesejahteraan rumah tangga. Pendapatan yang terbilang besar pada saat harga jual lada belum menurun secara drastis dan masih stabil menyebabkan pemenuhan akan fasilitas rumah tangga mampu tercukupi dan terjamin secara baik.

Tabel 3. Rata-rata perolehan kelas setiap indikator.

\begin{tabular}{lrcc}
\hline \multirow{2}{*}{\multicolumn{1}{c}{ Indikator }} & \multicolumn{3}{c}{ Jumlah (jiwa) } \\
\cline { 2 - 4 } & \multicolumn{3}{c}{ Kelas } \\
& Baik & Cukup & Kurang \\
\hline Kependudukan & 0 & 43 & 0 \\
Kesehatan dan gizi & 22 & 21 & 0 \\
Pendidikan & 0 & 43 & 0 \\
Ketenagakerjaan & 34 & 9 & 0 \\
Taraf dan pola konsumsi & 13 & 30 & 0 \\
Perumahan dan lingkungan & 43 & 0 & 0 \\
Sosial dan lain & 0 & 35 & 8 \\
\hline
\end{tabular}

Tabel 4. Sebaran kesejahteraan rumah tangga petani lada BPS (2014).

\begin{tabular}{lcrr}
\hline Kategori & $\begin{array}{c}\text { Kelas } \\
\text { interval }\end{array}$ & $\begin{array}{c}\text { Jumlah } \\
\text { (jiwa) }\end{array}$ & $\begin{array}{c}\text { Persentase } \\
(\%)\end{array}$ \\
\hline Sejahtera & $15-21$ & 43 & 100,00 \\
Belum Sejahtera & $7-14$ & 0 & 00,00 \\
\hline Jumlah & & 43 & 100,00 \\
\hline
\end{tabular}


Tabel 5. Hasil perolehan skor indikator kesejahteraan subjektif.

\begin{tabular}{|c|c|c|c|}
\hline \multirow{2}{*}{ Indikator Kesejahteraan Subjektif } & \multicolumn{3}{|c|}{ Skor } \\
\hline & 1 & 2 & 3 \\
\hline \multicolumn{4}{|l|}{ Dimensi Ekonomi } \\
\hline $\begin{array}{l}\text { a. Keluarga merasa puas dengan kondisi } \\
\text { keuangan saat ini }\end{array}$ & 24 & 18 & 1 \\
\hline $\begin{array}{l}\text { b. Pendapatan dari usahatani lada mencukupi } \\
\text { semua kebutuhan }\end{array}$ & 20 & 22 & 1 \\
\hline c. Bisa meluangkan waktu untuk & & & \\
\hline $\begin{array}{l}\text { mengembangkan diri karena pendapatan } \\
\text { mencukupi }\end{array}$ & 4 & 29 & 10 \\
\hline $\begin{array}{l}\text { d. Bisa melakukan hal yang diinginkan tanpa } \\
\text { khawatir memengaruhi keuangan keluarga }\end{array}$ & 10 & 27 & 6 \\
\hline $\begin{array}{l}\text { e. Keluarga tidak merasa kesulitan memenuhi } \\
\text { pembiayaan pendidikan anggota keluarga }\end{array}$ & 2 & 24 & 17 \\
\hline $\begin{array}{l}\text { f.Keluarga tidak mengalami kesulitan dalam } \\
\text { membiayai kesehatan }\end{array}$ & 4 & 31 & 8 \\
\hline $\begin{array}{l}\text { g. Keluarga memiliki tabungan yang cukup } \\
\text { untuk memenuhi kebutuhan yang tak terduga }\end{array}$ & 5 & 30 & 8 \\
\hline h. Keluarga merasa usahatani lada & & & \\
\hline $\begin{array}{l}\text { berkontribusi besar dalam menghasilkan } \\
\text { pendapatan rumah tangga }\end{array}$ & 0 & 15 & 28 \\
\hline $\begin{array}{l}\text { i. Keluarga puas terhadap kepemilikan lahan } \\
\text { pertanian }\end{array}$ & 1 & 25 & 17 \\
\hline $\begin{array}{l}\text { j. Keluarga merasa puas terhadap kepemilikan } \\
\text { asset keluarga }\end{array}$ & 1 & 25 & 17 \\
\hline Jumlah & 71 & 246 & 113 \\
\hline
\end{tabular}

Dimensi Fisik

a. Rumah yang dimiliki sudah layak huni

b. Kondisi rumah dan fasilitas di dalamnya sudah membuat nyaman keluarga

$\begin{array}{lll}0 & 16 & 27\end{array}$

$\begin{array}{lll}0 & 19 & 24\end{array}$

c. Pakaian yang diperoleh keluarga sudah dianggap layak dan mencukupi

d. Keluarga merasa puas dengan keadaan kesehatan fisik saat ini

e. Membawa setiap anggota keluarga yang sakit ke tempat pengobatan medis

f.Keluarga merasa puas dengan kondisi makanan dan minuman sehari-hari Jumlah

Dimensi Psikologis

a. Keluarga tidak mengalami gangguan kesehatan sehingga mengganggu aktivitas $\quad \begin{array}{lll}0 & 21 & 22\end{array}$ sehari-hari yang dilakukan

b. Keluarga merasa bebas menjalankan ibadah $\quad \begin{array}{lll}0 & 10 & 33\end{array}$

c. Keluarga puas dengan keadaan spiritual/mental

$1 \quad 21 \quad 21$

d. Keluarga aman dari gangguan kejahatan $\begin{array}{llll}\text { seperti penodongan, perampokan, pemerasan } & 0 & 15 & 28\end{array}$

e. Keluarga puas dengan pekerjaan sekarang $\quad \begin{array}{llll}0 & 13 & 30\end{array}$

f.Keluarga merasa puas dengan pengetahuan pertanian yang dimiliki

g. Keluarga selalu optimis dengan keputusan yang diambil untuk kehidupan masa depan Jumlah

$2121 \quad 1$

$\begin{array}{lll}5 & 16 & 22\end{array}$

$27 \quad 117 \quad 157$

\section{Dimensi Sosial}

a. Keluarga mampu ikut terlibat dalam kegiatan di lingkungan tempat tinggal

$\begin{array}{lll}0 & 18 \quad 35\end{array}$

b. Keluarga merasa antar anggota keluarga memiliki hubungan yang harmonis

$\begin{array}{lll}0 & 21 & 22\end{array}$

c. Keluarga merasa memiliki hubungan yang harmonis dalam bermasyarakat

$1 \quad 21 \quad 21$

d. Keluarga sering membantu tetangga/ orang lain dalambentuk material atau non material Jumlah
Hasil tersebut sejalan dengan penelitian Pranata, Widjaya dan Silviyanti (2019) yang menyatakan bahwa mayoritas petani lada $(85,48 \%)$ petani lada tergolong dalam kategori rumah tangga sejahtera.

\section{Kesejahteraan Rumah Tangga Petani Lada Berdasarkan Indikator Subjektif}

Menurut Miswati, Lestari, dan Marlina (2019), kesejahteraan subjektif merupakan kondisi dan kelayakan kehidupan yang dinilai oleh dirinya sendiri. Pada pengukuran tingkat kesejahteraan subjektif pertanyaan yang digunakan ditekankan pada persepsi petani atas apa yang dirasakan saat ini. Pengukuran dilakukan melalui pendekatan empat dimensi yaitu ekonomi, fisik, psikologi, dan sosial. Kesejahteraan subjektif dapat disimpulkan melalui tiga kategori yaitu rendah, sedang, dan tinggi. Hasil penelitian menunjukkan bahwa pada dimensi fisik, indikator yang memiliki nilai skor 1 (rendah) terbanyak merupakan kepuasan keluarga

Pada Tabel 6 dapat disimpulkan bahwa menurut indikator kesejehteraan subjektif petani lada di Kecamatan Melinting berada pada tingkat kesejahteraan rendah sebanyak 34,88 persen, sedang 44,19 persen, dan tinggi 20,93 persen. Hal ini menunjukkan bahwa walaupun secara objektif petani lada berada pada kategori sejahtera secara keseluruhan, namun pada pengukuran secara subjektif masih terdapat beberapa petani dengan tingkat kesejahteraan sedang dan rendah. Tingkat kepuasan atas pemenuhan kebutuhan jika dilihat secara keseluruhan baik dari dimensi ekonomi, fisik, sosial, dan psikologi atas pendapatan yang diterima petani setelah terjadi penurunan harga yang sangat signifikan ini, dirasa belum mencapai tingkat yang memuaskan bagi petani. Pendapatan yang diterima belum dapat menutupi pengeluaran yang harus dikeluarkan, baik untuk usahatani lada yang dilakukan maupun pemenuhan kebutuhan dasar rumah tangga. Walaupun secara fisik bangunan rumah dan fasilitas rumah tangga sudah cukup baik, namun bagi petani untuk tingkat kemapanan ekonomi masih termasuk kurang mencukupi.

Selain dari sifat manusia yang selalu merasa tidak puas, pendapatan yang semakin menurun juga menjadi faktor munculnya perbedaan antara tingkat kesejahteraan subjektif dan objektif petani. Penurunan harga lada yang terjadi secara signifikan dari harga lada pada tahun-tahun sebelumnya mengakibatkan kepuasan petani akan penerimaan yang didapatkan saat ini juga menurun, sehingga mempengaruhi penilaian petani 
terhadap kualitas hidupnya dari sebelum terjadi penurunan harga dengan setelah terjadi penurunan harga. Petani beranggapan bahwa dengan menurunnya harga lada, walaupun secara fisik kebutuhan dapat terpenuhi, namun secara psikologi petani belum mampu secara maksimal memenuhi kebutuhan sehari-hari. Petani selalu merasa cemas akan kemampuan memenuhi kebutuhan dengan pendapatan yang terbilang minim dari usahatani lada saat ini. Petani juga menganggap bahwa dengan pendapatan yang diterima pada saat terjadi penurunan harga ini, petani tidak mampu menyisikan pendapatannya untuk keperluan mendadak.

Berdasarkan hasil tersebut, maka dapat dikatakan bahwa kesejahteraan secara objektif tidak selalu berbanding lurus dengan kesejahteraan subjektif. Hasil tersebut sejalan dengan penelitian yang dilakukan oleh Adriadi (2019) terhadap kesejahteraan subjektif petani tebu di Kecamatan Bunga Mayang pasca terjadi penurunan harga yang signifikan. Kesejahteraan subjektif menggambarkan bagaimana petani menilai dan merasakan kualitas hidupnya melalui apa yang telah dicapai selama ini, terlepas dari apa saja dan bagaimana kesejahteraan objektif yang dimiliki.

\section{KESIMPULAN}

Pendapatan rumah tangga petani lada di Kecamatan Melinting termasuk ke dalam golongan kategori pendapatan rendah yaitu sebesar Rp1.691.026,16/bulan yang bersumber dari pendapatan on farm lada, on farm non lada, off farm, dan non farm. Usahatani lada di Kecamatan Melinting apabila dilihat dari $\mathrm{R} / \mathrm{C}$ atas biaya tunai sebesar 2,78 termasuk dalam usahatani yang menguntungkan dan layak untuk diteruskan, namun jika dilihat dari $\mathrm{R} / \mathrm{C}$ atas biaya total sebesar 0,88 maka termasuk dalam usahatani yang belum menguntungkan. Secara objektif 100 persen petani lada berada pada kategori sejahtera dan secara subjektif hanya sebanyak 20,93 persen, sedangkan sisanya sebesar 34,88 persen termasuk dalam kategori rendah dan 44, 19 persen dalam kategori sedang.

Tabel 6. Tingkat kesejahteraan subjektif petani lada di Kecamatan Melinting.

\begin{tabular}{lccc}
\hline Kategori & Interval & $\begin{array}{c}\text { Jumlah } \\
\text { (jiwa) }\end{array}$ & Persentase (\%) \\
\hline Rendah & $49-58$ & 15 & 34,88 \\
Sedang & $59-68$ & 19 & 44,19 \\
Tinggi & $>68$ & 9 & 20,93 \\
\hline Jumlah & & 43 & 100,00 \\
\hline
\end{tabular}

\section{DAFTAR PUSTAKA}

Adriadi TM. 2019. Analisis Pendapatan dan Tingkat Kesejahteraan Rumah Tangga Petani Tebu Rakyat di Kecamatan Bunga Mayang Kabupaten Lampung Utara. Skripsi. Fakultas Pertanian Universitas Lampung. Bandar Lampung.

BPS [Badan Pusat Statistik]. 2014. Indikator Kesejahteraan Rakyat (Welfare Indicators) 2014. http://bps.go.id/. [28 November 2019]. . 2019. Laporan Perekonomian Indonesia .http://bps.go.id/. [2 November 2019]

2016. Penggolongan Pendapatan Penduduk. http://bps.go.id/. [28 November 2019].

Canita PL, Haryono D, dan Kasymir E. 2017. Analisis pendapatan dan tingkat kesejahteraan rumah tangga petani pisang di Kecamatan Padang Cermin Kabupaten Pesawaran. Jurnal Ilmu Ilmu Agribisnis, 5(3) : 235-241. http://jurnal.fp.unila.ac. id/ index.php/JIA/article/view/1635/1461. [02 November 2020]

Dinas Perkebunan Provinsi Lampung. 2017. Statistik Perkebunan Lampung. Dinas Perkebunan Lampung. Bandar Lampung.

Handini LN, Abidin Z, dan Hassanudin T. 2019. Pendapatan usahatani dan tingkat ketahanan pangan rumah tangga petani lada hitam di Desa Sukadana Baru, Kecamatan Marga Tiga, Lampung Timur. Jurnal Ilmu Ilmu Agribisnis, 7

507-514.

https://jurnal.fp.junila.ac.id/index.php/JIA /article/view/3866/2834.[6 November 2019].

Kementerian Pertanian Republik Indonesia. 2018. Buku Statistik Pertanian 2018. http://epublikasi.setjen.pertanian.go.id/arsippe rstatistikan/160statistik/statistikpertanian/ [ 17 Mei 2019].

Miswati AS, Lestari DAH, dan Marlina L. 2019. Pendapatan dan kesejahteraan subjektif keluarga petani alih komoditi padi ke karet di Kecamatan Abung Surakarta Lampung Utara. Jurnal Ilmu Ilmu Agribisnis , 8(2) : 334-341. https:// jurnal.fp.unila. ac.id/index.php/JIA/article/view/4074 September 2019].

Meliyana R, Zakaria WA, dan Nurmayasari, I. 2013. Daya saing lada hitam di Kecamatan Abung Tinggi Kabupaten Lampung Utara. Jurnal Ilmu Ilmu Agribisnis, 1(4) : 271-277. https://jurnal.fp.unila.ac.id/index.php/JIA/artic le/view/702November 2019]. 
Muhsin SW. 2014. Peran Gender dalam Pengambilan Keputusan dan Kesejahteraan Subjektif pada Keluarga Usia Pensiun. Skripsi. Fakultas Ekologi Manusia Institut Pertanian Bogor. Bogor. https://repository. ipb.ac.id / [6 November 2019].

Patra RS, Ismono RH, dan Nugraha A. 2019. Struktur dan distribusi pendapatan serta kesejahteraan petani kelapa sawit rakyat di Kabupaten Tulang Bawang. Jurnal Ilmu Ilmu Agribisnis, $\quad 7(3)$ : 35-360. http://jurnal.fp.unila.ac.id/index.php /JIA /article/view/3773/2774. [01 Oktober 2020].

Pranata Y, Widjaya S, dan Silviyanti S. 2019. Analisis pendapatan dan tingkat kesejahteraan petani lada di Kecamatan Tanjung Raja, Kabupaten Lampung Utara. Jurnal Ilmu Ilmu Agribisnis, 7(2) : 383-390. http://jurnal.fp.unila.ac.id/index.php/ JIA/article/view/3777/ [01 Oktober 2020].

Prasetio DE, Widjaya S, dan Murniati, K. 2020. Pendapatan dan kesejahateraan petani padi sawah di Kabupaten Lampung Tengah. Jurnal Ilmu Ilmu Agribisnis, 8(3) : 403-410. https://jurnal.fp.unila.ac.id/
index.php/JIA/article/view/3064 https://jurnal. fp.unila.ac.id/index.php/JIA/article/view/3064 .php JIA/article/view/4435/pdf. [02 November 2020]

Soekartawi. 2002. Prinsip Dasar Manajemen Pemasaran Hasil-Hasil Pertanian; Teori dan Aplikasinya. Raja Grafindo Persada. Jakarta.

Simamora, WN, Zakaria WA, dan Kasymir, A. 2020. Pendapatan dan tingkat kesejahteraan pertanian di Kelurahan Kedaung Kecamatan Kemiling Kota Bandar Lampung. Jurnal Ilmu Ilmu Agribisnis, 8(2) : 257-264. http://jurnal.fp.unila.ac.id/index.php /JIA/article/view/4062/2958. [02 November 2020]

Sugiarto. 2003. Teknik Sampling. Gramedia. Jakarta.

Togatorop SM, Haryono D, dan Rosanti N. 2014. Pendapatan dan tingkat kesejahteraan petani lada di Kecamatan Gunung Labuhan Kabupaten Way Kanan. Jurnal Ilmu Ilmu $\begin{array}{llll}\text { Agribisnis, } & \text { 2(3) } \quad \text { : } & 268\end{array}$ 275.http://jurnal.fp.unila.ac.id/index.php/JIA/a rticl e/view/810/740. [21 September 2018]. 